\title{
Study Of Fuzzy Goal Programming Model To Production Planning Problems Approach
}

\author{
Desi Vinsensia1 $^{*}$, Yulia Utami², Mian Sari Simanjuntak³ ${ }^{3}$ Arya Riski Tarigan ${ }^{4}$ \\ ${ }^{1}$ Manajemen Informatika, STMIK Pelita Nusantara, Jl. Iskandar Muda No. 1 Medan, Sumatera Utara, 20154, \\ Indonesia \\ 2,3,4Teknik Informatika, STMIK Pelita Nusantara, Jl. Iskandar Muda No. 1 Medan, Sumatera Utara, 20154, Indonesia \\ Email: 1desivinsensia87@gmail.com*; 2yulia_utami@rocketmail.com \\ *correspondence author
}

A R T I C L E I N F O

Article history:

Received: Jul 13, 2021;

Revised: Aug 22, 2021;

Accepted: Aug 27, 2021;

Available online: Sep 30, 2021.

Keywords:

Production Planning Problems;

Goal Programming;

Fuzzy Goal Programming;

Optimal Solutions.

\section{A B S T RAC T}

The production planning system can provide satisfaction to the manufacture with the desire target and also with the available raw materials. In achieving the target of goals also face a situation of uncertainty (fuzzy). The aims of this study is proposed the model of fuzzy goal programming approach to optimize production planning system. In this model obtaining maximizing profit and revenue with consider minimize costs of labor cost, raw materials cost, time machine production, and also inventory cost. The numerical example is illustrate that the fuzzy goal programming model can optimize optimize production and profit according desired of decision maker.

\section{Introduction}

The competitive competition among company on revolution industry 4.0e era encourage the companies to optimize production planning. Production planning used to determine the type and quantity each products of company in the future and also is a process to producing goods at certain period to predicted or scheduled through labour resources, raw materials, machinery[1][2]. Production planning ia manufacturing process to plan the achievement of goal efficiently[3]. Production panning requires cooperation between multiple functions among maximize profit and minimize cost also level of inventory [4]. The goal programming model is one of technique that used decision making problems that involve multiple goals to simultaneous completion and also the goals be interrelated and conficting [5][6].In real life, not only deals with certain factor but also facing uncertainty objective function in optimization wich is can be express by means triangular fuzzy numbers [7].

In this paper study goal programming model combine fuzzy method to maximize profit and revenue with consider uncertainty problems. The aim of this study is proposed the model of fuzzy goal programming approach in production planning. Fuzzy method capable of handling data that contains uncertainty and also can combine with other methods to contribute te optimal decision making and efficiently [8]. Fuzzy goal programming is to handle inaccuracies data input and allows solving the congestion management problems [9]. The fuzzy goal programming model is develop to profit optimization [10] by minimizing cost of labour [11], raw materials [12]. Fuzzy goal programming method can used to optimize a hypothetical sustainable wind energy portfolio [13]. This method effectively the decision of production planning with consider profit and demand tolerance value [14], related maximize revenue and increasing production with minimum cost [15], determine multiobjective transportation problems [16]. In other part, the fuzzy goal programming method using to selective maintenance allocation of reliability [17]. Based on the above background, this research use combination 
fuzzy method and goal programming to build a model to optimize profit and revenue with consider minimize raw material, labour cost, time machine production, level of inventory cost. The results model expected to be able used to optimize production planning problems.

\section{Research Method}

In this research, proposed the model of fuzzy goal programming approach in production planning. The research steps there are several stages. The stages for the formulation of the fuzzy goal programming model were propose [18][19][20][21], among others: (1) Determine the decision variables, (2) Determine the forms of constraints, (3) Forming of linear program models based on the established objective and constraint functions, (4) Finding the optimal solution for each models, (5) Forming the membership function of the optimal solution according to the fuzzy membership function, (6) Forming of fuzzy goal programming model [22]. Furthermore, the fuzzy goal programming model is applied to the case with small medium enterprise (SME) to evaluate the model that has been made, the results are tested[23][24][25]. The results of the application in the case of SME following the model with fuzzy goal programming that has been built then analyzed to see how the results of the optimum solution in production planning for SME's are applied. Conclusions outlined in the last part.

\section{Results And Discussion}

To formulated fuzzy goal programming model, steps are needed to identify decision variables, objective functions, constraint functions, and form fuzzy membership functions. Here following steps:

a. The decision variables in this model is number of production on each kind of products to produces i.e $x_{1}, x_{2}, x_{3}, \ldots, x_{n}$.

b. The objective functions to propose in this model are:

1) The objective function to maximize earns

$$
P(x)=q_{1} x_{1}+q_{2} x_{2}+\ldots+q_{n} x_{n}=\sum_{1}^{n} q_{n} x_{n}
$$

2) The objective function to maximize profit

$$
\begin{aligned}
& Z(x)=\left(q_{1}-c_{1}-r_{1}-t_{1}\right) x_{1}+\left(q_{2}-c_{2}-r_{2}-t_{2}\right) x_{2}+\ldots+\left(q_{n}-c_{n}-r_{n}-t_{n}\right) x_{n} \\
& =\sum_{1}^{n}\left(q_{n}-c_{n}-r_{n}-t_{n}\right) x_{n}
\end{aligned}
$$

3) The objective function to minimize the cost raw materials

$$
T(x)=r_{1} x_{1}+r_{2} x_{2}+\ldots+r_{n} x_{n}=\sum_{1}^{n} r_{n} x_{n}
$$

4) The objective function to minimize the cost of labor

$$
B(x)=c_{1} x_{1}+c_{2} x_{2}+\ldots+c_{n} x_{n}=\sum_{1}^{n} c_{n} x_{n}
$$

5) The objective function to minimize work of production time

$$
U(x)=v_{1} x_{1}+v_{2} x_{2}+\ldots+v_{n} x_{n}=\sum_{1}^{n} v_{n} x_{n}
$$

6) The objective function to minimize cost of inventory

$$
S(x)=t_{1} x_{1}+t_{2} x_{2}+\ldots+t_{n} x_{n}=\sum_{1}^{n} t_{n} x_{n}
$$

c. The constraint in this propose model that raw materials each product 


$$
\begin{aligned}
& a_{11} x_{1}+a_{12} x_{2}+\ldots+a_{1 i} x_{i}+\ldots+a_{1 n} x_{n} \leq w_{1} \\
& a_{21} x_{1}+a_{22} x_{2}+\ldots+a_{2 i} x_{i}+\ldots+a_{2 n} x_{n} \leq w_{1} \\
& \cdot \\
& \cdot \\
& a_{j 1} x_{1}+a_{j 2} x_{2}+\ldots+a_{j i} x_{i}+\ldots+a_{j n} x_{n} \leq w_{j} \\
& \cdot \\
& \cdot \\
& a_{m 1} x_{1}+a_{m 2} x_{2}+\ldots+a_{m i} x_{i}+\ldots+a_{m n} x_{n} \leq w_{m} \\
& x_{i} \geq 0, i=1, \ldots, n ; j=1, \ldots, m
\end{aligned}
$$

(7)

d. The Fuzzy membership function to propose the model:

$$
\begin{aligned}
& \mu_{z}(x)=\left\{\begin{array}{cl}
1, & Z(x) \geq Z^{*} \\
\frac{Z(x)-\bar{Z}}{Z^{*}-\bar{Z}}, & \bar{Z} \leq Z(x) \leq Z^{*} \\
0, & Z(x) \leq \bar{Z}
\end{array}\right. \\
& \mu_{B}(x)=\left\{\begin{array}{cl}
1, & B(x) \leq B^{*} \\
\bar{B}-B(x) & B^{*} \leq B(x) \leq \bar{B} \\
\bar{B}-B^{*}, & B(x) \geq \bar{B}
\end{array}\right. \\
& \mu_{T}(x)=\left\{\begin{array}{cc}
1, & T(x) \leq T^{*} \\
\bar{T}-T(x) & T^{*} \leq T(x) \leq \bar{T} \\
\bar{T}-T^{*}, & T(x) \geq \bar{T}
\end{array}\right. \\
& \mu_{U}(x)=\left\{\begin{array}{cc}
1, & U(x) \leq U^{*} \\
\bar{U}-U(x) & U^{*} \leq U(x) \leq \bar{U} \\
\bar{U}-U^{*}, & U(x) \geq \bar{U}
\end{array}\right. \\
& \mu_{S}(x)=\left\{\begin{array}{cl}
1, & S(x) \leq S^{*} \\
\frac{\bar{S}-S(x)}{\bar{S}-S^{*}}, & S^{*} \leq S(x) \leq \bar{S} \\
0, & S(x) \geq \bar{S}
\end{array}\right.
\end{aligned}
$$

Equation (1),(2),(3),(4),(5),(6) and (8),(9),(10),(11),(12) constraints can be formed for the proposed fuzzy goal programming model. Thus, the fuzzy goal programming model is formulated as follows:

Maximize $: \alpha$

Subject to 


$$
\begin{aligned}
& \sum_{1}^{n} q_{n} x_{n}-\left(P^{*}-\bar{P}\right) \alpha \geq \bar{P} \\
& \sum_{1}^{n}\left(q_{n}-c_{n}-r_{n}-t_{n}\right) x_{n}-\left(Z^{*}-\bar{Z}\right) \alpha \geq \bar{Z} \\
& \sum_{1}^{n} r_{n} x_{n}+\left(\bar{T}-T^{*}\right) \alpha \leq \bar{T} \\
& \sum_{1}^{n} c_{n} x_{n}+\left(\bar{B}-B^{*}\right) \alpha \leq \bar{B} \\
& \sum_{1}^{n} v_{n} x_{n}+\left(\bar{U}-U^{*}\right) \alpha \leq \bar{U} \\
& \sum_{1}^{n} t_{n} x_{n}+\left(\bar{S}-S^{*}\right) \alpha \leq \bar{S} \\
& a_{11} x_{1}+a_{12} x_{2}+\ldots+a_{1 i} x_{i}+\ldots+a_{1 n} x_{n} \leq w_{1} \\
& a_{21} x_{1}+a_{22} x_{2}+\ldots+a_{2 i} x_{i}+\ldots+a_{2 n} x_{n} \leq w_{1} \\
& . \\
& \cdot \\
& \cdot \\
& a_{m 1} x_{1}+a_{m 2} x_{2}+\ldots+a_{m i} x_{i}+\ldots+a_{m n} x_{n} \leq w_{m} \\
& x_{i} \geq 0, i=1, \ldots, n ; j=1, \ldots, m \\
& . \\
& . \\
&
\end{aligned}
$$

\begin{tabular}{|c|c|c|c|c|c|c|c|c|c|c|}
\hline \multirow[b]{2}{*}{$\begin{array}{c}\text { Product } \\
\mathrm{s}\end{array}$} & \multirow{2}{*}{$\begin{array}{l}\text { Sellin } \\
\text { g } \\
\text { Price }\end{array}$} & \multirow{2}{*}{$\begin{array}{c}\text { Cost } \\
\text { Material } \\
\text { S }\end{array}$} & \multirow{2}{*}{$\begin{array}{l}\text { Cost } \\
\text { of } \\
\text { Labo } \\
\text { r }\end{array}$} & \multirow{2}{*}{$\begin{array}{c}\text { Cost of } \\
\text { inventot } \\
\mathrm{y}\end{array}$} & \multirow{2}{*}{$\begin{array}{c}\text { Time } \\
\text { productio } \\
\mathrm{n}\end{array}$} & \multicolumn{4}{|c|}{ Type of materials } & \multirow{2}{*}{$\begin{array}{l}\text { Tota } \\
\text { l (gr) }\end{array}$} \\
\hline & & & & & & $\begin{array}{l}\text { Cotto } \\
n\end{array}$ & $\begin{array}{l}\text { Scub } \\
\text { a }\end{array}$ & $\begin{array}{l}\text { Spande } \\
\mathrm{x}\end{array}$ & $\begin{array}{l}\text { Rayo } \\
\mathrm{n}\end{array}$ & \\
\hline Shirt & 4500 & 14.35 & 72.35 & 54.7 & 5.2 & $85 \%$ & $20 /$ & & $10 \%$ & 22 \\
\hline T-Shirt & 3450 & 23.6 & 68.32 & 54.7 & 6 & $85 \%$ & $2 \%$ & $3 \%$ & $10 \%$ & 18 \\
\hline Tunik & 4700 & 10.5 & 72.35 & 54.7 & 5.2 & 6204 & 1004 & POQ & 100 & 22 \\
\hline Gamis & 6030 & 13.2 & 72.35 & 54.7 & 5.2 & $62 \%$ & $10 \%$ & $20 \%$ & $18 \%$ & 18 \\
\hline Pajama & 4250 & 9.14 & 68.32 & 54.7 & 6 & & & & & 22 \\
\hline $\begin{array}{l}\text { Home } \\
\text { dress }\end{array}$ & 6600 & 22.31 & 68.32 & 54.7 & 6 & $50 \%$ & $3 \%$ & $5 \%$ & $42 \%$ & 18 \\
\hline Pants & 3800 & 7.23 & 72.35 & 54.7 & 5.2 & $60 \%$ & $50 \%$ & 10 & & 22 \\
\hline Skirts & 4600 & 24.3 & 68.32 & 54.7 & 6 & $36 \%$ & $50 \%$ & $10 \%$ & $4 \%$ & 18 \\
\hline
\end{tabular}

Table 1.

Detail of Products UD. ABC

Table 1 is numerical example for this research, that contains the description details of products from UD. ABC. The enterprenuer of UD. ABC's gives a minimum production limits for each product of 200.000, the minimum limit for the use of materials and the maximum limit for the use of brands for each type of product is 700.000 types of brands. In addition, the number of materials for each kind are $2253600 \mathrm{~kg}$ cotton, 561,783.65kg scuba, 456453,45 kg spandex, and 140769, $55 \mathrm{~kg}$ rayon. This problems will be solve using model (13) and goal programming model. 
Thus, the decision variables as follows:

$x_{1}$ : number of Shirt

$x_{2}:$ number of T-shirt

$x_{3}:$ number of tunik

$x_{4}:$ number of Gamis

$x_{5}$ : number of Pajama

$x_{6}:$ number of home dress

$x_{7}:$ number of pants

$x_{8}$ : number of skirt

Based on problem above, the Goal Programming model be formulate as follows:

Maximize:

$4500 x_{1}+3400 x_{2}+4700 x_{3}+6030 x_{4}+4250 x_{5}+6600 x_{6}+3800 x_{7}+4600 x_{8}$

$4258,45 x_{1}+3303,38 x_{2}+4562,45 x_{3}+5889,75 x_{4}+4117,84 x_{5}+6454,67 x_{6}+3665,72 x_{7}+4452,68 x_{8}$

Minimize:

$72,35 x_{1}+68,32 x_{2}+72,35 x_{3}+72,35 x_{4}+68,32 x_{5}+68,32 x_{6}+72,35 x_{7}+68,32 x_{8}$

$14,35 x_{1}+23,6 x_{2}+10,5 x_{3}+13,2 x_{4}+9,14 x_{5}+22,31 x_{6}+7,23 x_{7}+24,3 x_{8}$

$5,2 x_{1}+6 x_{2}+5,2 x_{3}+5,2 x_{4}+6 x_{5}+6 x_{6}+5,2 x_{7}+6 x_{8}$

$54,7 x_{1}+54,7 x_{2}+54,7 x_{3} 54,7 x_{4}+54,7 x_{5}+54,7 x_{6}+54,7 x_{7}+54,7 x_{8}$

Subject to:

$$
\begin{aligned}
& 18,7 x_{1}+15,3 x_{2}+13,64 x_{3}+11,16 x_{4}+11 x_{5}+9 x_{6}+7,92 x_{7}+6,48 x_{8} \leq 2253600000 \\
& 0,44 x_{1}+0,36 x_{2}+2,2 x_{3}+1,8 x_{4}+0,66 x_{5}+0,48 x_{6}+11 x_{7}+9 x_{8} \leq 561783650 \\
& 2,2 x_{1}+1,8 x_{2}+3,96 x_{3}+15,24 x_{4}+9,24 x_{5}+7,56 x_{6}+0,88 x_{7}+0,72 x_{8} \leq 456453450 \\
& 5,2 x_{1}+6 x_{2}+5,2 x_{3}+5,2 x_{4}+6 x_{5}+6 x_{6}+5,2 x_{7}+6 x_{8} \leq 140769550 \\
& x_{1}+x_{2}+x_{3}+x_{4}+x_{5}+x_{6}+x_{7}+x_{8} \leq 700000 \\
& x_{1}, x_{2}, \ldots, x_{8} \geq 200000
\end{aligned}
$$

Furthermore, based on goal programming model can be formulated the Fuzzy Goal Programming model as follows:

Maximize: $\quad \alpha$

Subject to:

$4358,45 x_{1}+3303,38 x_{2}+4562,45 x_{3}+5889,75 x_{4}+4117,84 x_{5}+6454,67 x_{6}+3665,72 x_{7}+4452,68 x_{8}$

$-765840 \alpha \leq 46877700$

$14,35 x_{1}+23,6 x_{2}+10,5 x_{3}+13,2 x_{4}+9,14 x_{5}+22,31 x_{6}+7,23 x_{7}+24,3 x_{8}+39973320 \alpha \leq 412125600$

$5,2 x_{1}+6 x_{2}+5,2 x_{3}+5,2 x_{4}+6 x_{5}+6 x_{6}+5,2 x_{7}+6 x_{8}+3845820 \alpha \leq 7281803$

$54,7 x_{1}+54,7 x_{2}+54,7 x_{3}+54,7 x_{4}+54,7 x_{5}+54,7 x_{6}+54,7 x_{7}+54,7 x_{8}+664560220 \alpha \leq 842065042$

$18,7 x_{1}+15,3 x_{2}+13,64 x_{3}+11,16 x_{4}+11 x_{5}+9 x_{6}+7,92 x_{7}+6,48 x_{8} \leq 2253600000$

$0,44 x_{1}+0,36 x_{2}+2,2 x_{3}+1,8 x_{4}+0,66 x_{5}+0,48 x_{6}+11 x_{7}+9 x_{8} \leq 561783650$

$2,2 x_{1}+1,8 x_{2}+3,96 x_{3}+15,24 x_{4}+9,24 x_{5}+7,56 x_{6}+0,88 x_{7}+0,72 x_{8} \leq 456453450$

$5,2 x_{1}+6 x_{2}+5,2 x_{3}+5,2 x_{4}+6 x_{5}+6 x_{6}+5,2 x_{7}+6 x_{8} \leq 140769550$

$x_{1}+x_{2}+x_{3}+x_{4}+x_{5}+x_{6}+x_{7}+x_{8} \leq 700000$

$x_{1}, x_{2}, \ldots, x_{8} \geq 200000$

$x_{i} \geq 0 ; \quad i=1, \ldots, 8$ 
By solving The result using fuzzy goal programming model and goal programming model are shown in table 2.

Table 2.

Results of Fuzzy Goal Programming Model

\begin{tabular}{lll}
\hline \multicolumn{1}{c}{ Objective function } & \multicolumn{1}{c}{ Fuzzy Goal Programming Model } & Goal Programming Model \\
\hline Profit and revenue & 4203565174 & 4412645311 \\
Raw material cost & 12114668 & 15203682 \\
Labour cost & 123405682 & 118942013 \\
Time of machine production & 6503021 & 7921004 \\
Inventory level cost & 22456170 & 24016957 \\
\hline
\end{tabular}

From results of table 2 show that there is different result between using fuzzy goal programming model and goal programming model for each given objective function. For example the objective function profit and revenue shows that using goal programming model graeter than fuzzy goal programming model. However, the profits and revenue obtained still within the range of profits desired of the entrepreneur. Furthermore, raw material cost, labour cost, time machine production and inventory level cost as the objective functions of this problems are on the desired of the enterpreneur. In other words, the fuzzy goal programming model given can be used in solved production planning problems. The fuzzy goal programming model build in this study, can be used to multi-criteria objective functions for optimized profit. The objective function to be achieved in this study for the purpose of maximizing revenue, profits, and minimizing the cost of materials, labour costs, working time of production machines and the cost of supply materials for production.

\section{Conclusion}

The formulation model has been build in this paper are fuzzy approach and goal programming that can solve production planning problems. Based on the case of study, it found that the profit gaints was different between fuzzy goal programming model and goal programming model. However, the profits still within the optimal solution like goals of the entrepreneur. That was in accordance with the multicriteria objective to optimize the companies profit. For future research, production planning problems with uncertain demand, and uncertain inventory stock might be interesting to be consider. Furthemore, extended the model dealing with that problems for propose new methods be considered as general future research topic.

\section{References}

[1] T. Nagalakshmi, "A Fuzzy Approach to solve a Team Allocation Problem using FDP technique," vol. 25, no. 4, pp. 6485-6493, 2021.

[2] T. Nagalakshmi and G. Uthra, "A new approach to find an optimal solution of a fuzzy linear programming problem by fuzzy dynamic programming," Int. J. Eng. Technol., vol. 7, no. 4.10 Special Issue 10, pp. 360-363, 2018, doi: 10.14419/ijet.v7i4.10.20935.

[3] E. B. Tirkolaee, A. Goli, and G.-W. Weber, "Multi-objective aggregate production planning model considering overtime and outsourcing options under fuzzy seasonal demand," in International Scientific-Technical Conference Manufacturing, 2019, pp. 81-96.

[4] S. Komsiyah and H. E. Centika, "A fuzzy goal programming model for production planning in furniture company," Procedia Comput. Sci., vol. 135, pp. 544-552, 2018.

[5] H. Taghizadeh, A. Bazrkar, and M. Abedzadeh, "Optimization production planning using fuzzy goal programming techniques," Mod. Appl. Sci., vol. 9, no. 9, p. 68, 2015.

[6] M. Hisjam, A. D. Guritno, N. Supriyatno, and S. D. Tandjung, "A Sustainable Partnership Model among Supply Chain Players in Wooden Furniture Industry Using Goal Programming," Agric. Agric. Sci. Procedia, vol. 3, pp. 154-158, 2015.

[7] O. Bahri, E.-G. Talbi, and N. Ben Amor, "A generic fuzzy approach for multi-objective optimization under uncertainty," Swarm Evol. Comput., vol. 40, pp. 166-183, 2018.

[8] I. Santoso, M. Sa'adah, and S. Wijana, "QFD and Fuzzy AHP for Formulating Product Concept of Probiotic 
Beverages for Diabetic," Telkomnika, vol. 15, no. 1, p. 391, 2017.

[9] P. Biswas and B. B. Pal, "A fuzzy goal programming method to solve congestion management problem using genetic algorithm," Decis. Mak. Appl. Manag. Eng., vol. 2, no. 2, pp. 36-53, 2019.

[10] V. Ghasemi, "A Fuzzy Goal Programming for Modeling Optimal Production Capacity of Shetabkar Company," Asian J. Res. Bus. Econ. Manag., vol. 5, no. 4, pp. 249-261, 2015.

[11] J. Purnama and S. Sajiyo, "Pengembangan Model Fuzzy Goal Programming Untuk Mengoptimalkan Produksi Pada Ukm Furniture," J. Simantec, vol. 9, no. 1, pp. 6-14, 2020, doi: 10.21107/simantec.v9i1.8998.

[12] J. Purnama, B. Setiawan, I. Santoso, and B. Yanuwiadi, "Decision support system fuzzy goal programming model to optimize benefits of SME furniture," Int. J. Eng. Technol., vol. 7, no. 4, pp. 6578-6584, 2018.

[13] A. Hocine, M. S. Guellil, E. Dogan, S. Ghouali, and N. Kouaissah, "A fuzzy goal programming with interval target model and its application to the decision problem of renewable energy planning," Environ. Ecol. Stat., vol. 27, no. 3, pp. 527-547, 2020.

[14] A. Ishak and P. Nababan, "The fuzzy goal programming approach to production planning of intermediate gear spare parts: a case study," J. Sist. dan Manaj. Ind., vol. 4, no. 2, pp. 137-143, 2020.

[15] F. Tampinongkol, A. Rindengan, and L. Latumakulita, "Aplikasi Fuzzy Goal Programming (Studi Kasus: UD. Sinar Sakti Manado)," d'CARTESIAN, vol. 4, no. 2, pp. 129-137, 2015.

[16] S. Rivaz, S. H. Nasseri, and M. Ziaseraji, "A Fuzzy Goal Programming Approach to Multiobjective Transportation Problems," Fuzzy Inf. Eng., vol. 0, no. 0, pp. 1-11, 2020, doi: 10.1080/16168658.2020.1794498.

[17] M. Kamal, U. M. Modibbo, A. AlArjani, and I. Ali, "Neutrosophic fuzzy goal programming approach in selective maintenance allocation of system reliability," Complex Intell. Syst., vol. 7, no. 2, pp. 1045-1059, 2021, doi: 10.1007/s40747-021-00269-1.

[18] S. A. Torabi 1 and E. Hassini, "Multi-site production planning integrating procurement and distribution plans in multi-echelon supply chains: an interactive fuzzy goal programming approach," Int. J. Prod. Res., vol. 47, no. 19, pp. 5475-5499, 2009.

[19] A. F. da Silva and F. A. S. Marins, "A Fuzzy Goal Programming model for solving aggregate production-planning problems under uncertainty: A case study in a Brazilian sugar mill," Energy Econ., vol. 45, pp. 196-204, 2014.

[20] H. Selim, C. Araz, and I. Ozkarahan, "Collaborative production-distribution planning in supply chain: a fuzzy goal programming approach,” Transp. Res. Part E Logist. Transp. Rev., vol. 44, no. 3, pp. 396-419, 2008.

[21] H. Selim and I. Ozkarahan, "A supply chain distribution network design model: an interactive fuzzy goal programming-based solution approach," Int. J. Adv. Manuf. Technol., vol. 36, no. 3, pp. 401-418, 2008.

[22] J. Mula, R. Poler, and J. P. Garcia, "MRP with flexible constraints: A fuzzy mathematical programming approach," Fuzzy sets Syst., vol. 157, no. 1, pp. 74-97, 2006.

[23] D. E. Ighravwe and S. A. Oke, "A combined fuzzy goal programming and Big-Bang Big-Crunch algorithm for workforce optimisation with facility layout consideration," Eng. J., vol. 19, no. 2, pp. 71-98, 2015.

[24] D. E. Ighravwe, S. A. Oke, and K. A. Adebiyi, "An enhanced reliability-oriented workforce planning model for process industry using combined fuzzy goal programming and differential evolution approach," J. Ind. Eng. Int., vol. 14, no. 1, pp. 185-212, 2018.

[25] C.-Y. Ku, C.-T. Chang, and H.-P. Ho, "Global supplier selection using fuzzy analytic hierarchy process and fuzzy goal programming," Qual. Quant., vol. 44, no. 4, pp. 623-640, 2010. 